\title{
Dopamine and Levodopa Prodrugs for the Treatment of Parkinson's Disease
}

\author{
Fatma Haddad, Maryam Sawalha, Yahya Khawaja, Anas Najjar and Rafik Karaman * \\ Department of Bioorganic \& Pharmaceutical Chemistry, Faculty of Pharmacy, Al-Quds University, \\ Jerusalem P.O. Box 20002, Palestine; iamfromhebron@hotmail.com (F.H.); maryam_khaled2@yahoo.com (M.S.); \\ yahya.khawaja@hotmail.com (Y.K.); nash.najjar@gmail.com (A.N.) \\ * Correspondence: dr_karaman@yahoo.com or rkaraman@staff.alquds.edu
}

Received: 4 December 2017; Accepted: 20 December 2017; Published: 25 December 2017

\begin{abstract}
Background: Parkinson's disease is an aggressive and progressive neurodegenerative disorder that depletes dopamine (DA) in the central nervous system. Dopamine replacement therapy, mainly through actual dopamine and its original prodrug L-dopa (LD), faces many challenges such as poor blood brain barrier penetration and decreased response to therapy with time. Methods: The prodrugs described herein are ester, amide, dimeric amide, carrier-mediated, peptide transport-mediated, cyclic, chemical delivery systems and enzyme-models prodrugs designed and made by chemical means, and their bioavailability was studied in animals. Results: A promising ester prodrug for intranasal delivery has been developed. LD methyl ester is currently in Phase III clinical trials. A series of amide prodrugs were synthesized with better stability than ester prodrugs. Both amide and dimeric amide prodrugs offer enhanced blood brain barrier (BBB) penetration and better pharmacokinetics. Attaching LD to sugars has been used to exploit glucose transport mechanisms into the brain. Conclusions: Till now, no DA prodrug has reached the pharmaceutical market, nevertheless, the future of utilizing prodrugs for the treatment of PD seems to be bright. For instance, LD ester prodrugs have demonstrated an adequate intranasal delivery of LD, thus enabling the absorption of therapeutic agents to the brain. Most of the amide, cyclic, peptidyl or chemical delivery systems of DA prodrugs demonstrated enhanced pharmacokinetic properties.
\end{abstract}

Keywords: dopamine; levodopa; prodrug; Parkinson's disease; blood brain barrier

\section{Introduction}

Dopamine (DA) is a natural neurotransmitter and neurohormone that exerts its action by binding to five DA receptors in the brain, $\mathrm{D}_{1-5}$ [1]. DA production represents the first steps in catecholamine synthesis and starts with phenylalanine which is hydroxylated to tyrosine, then again to levodopa (LD) and finally, through decarboxylation, to DA (Scheme 1). This cascade is accomplished and catalysed with the aid of three enzymes. The rate limiting enzyme is tyrosine hydroxylase. This can be inhibited by catecholamine neurotransmitters through negative feedback to keep proper regulation of DA [2]. DA plays several and variant roles in the body systems; including central nervous system (CNS), circulatory, renal, digestive and immune systems (Figure 1). Its role in the CNS is a cornerstone in controlling movement and emotion [1]. 
l-Phenylalanine

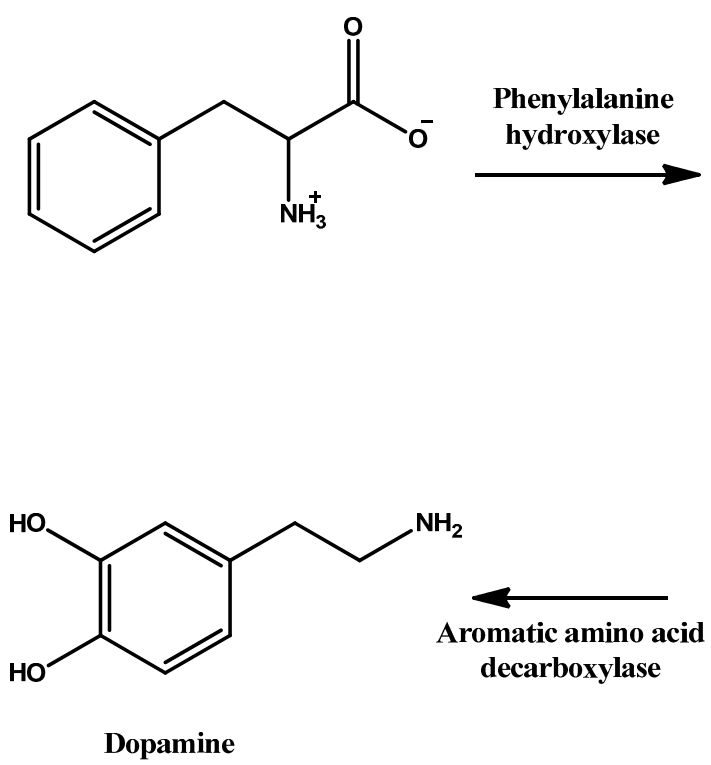

l-tyrosine<smiles>CC(C)Cc1ccc(O)c(O)c1</smiles>

Scheme 1. Dopamine synthesis pathway.

Parkinson's disease (PD) is the second most common neurodegenerative disorder, affecting about $1 \%$ of persons over the age of 60 , causing progressive neurodegenerative movement disorders [3], along with cognitive manifestations; making the patient neurologically disabled. PD has global distribution with no gender preference [4,5]. The pathological explanation of PD symptoms is mainly due to the diminished dopamine in the basal ganglia. In the healthy brain, exactly in the midbrain region, there is an area named substantia nigra where the degeneration of neuronal cells happens. This area communicates with the striatum using the chemical messenger DA. Whereas, in the diseased brain, these cells are depleted, hence, the DA deficits in striatal cells. The other major neuropathological symptom of PD is the existence of Lewy bodies and Lewy neuritis [6]. The exact cause of neuronal deathis still not completely understood but might be due to proteasomal as well as mitochondrial dysfunction [4,7].
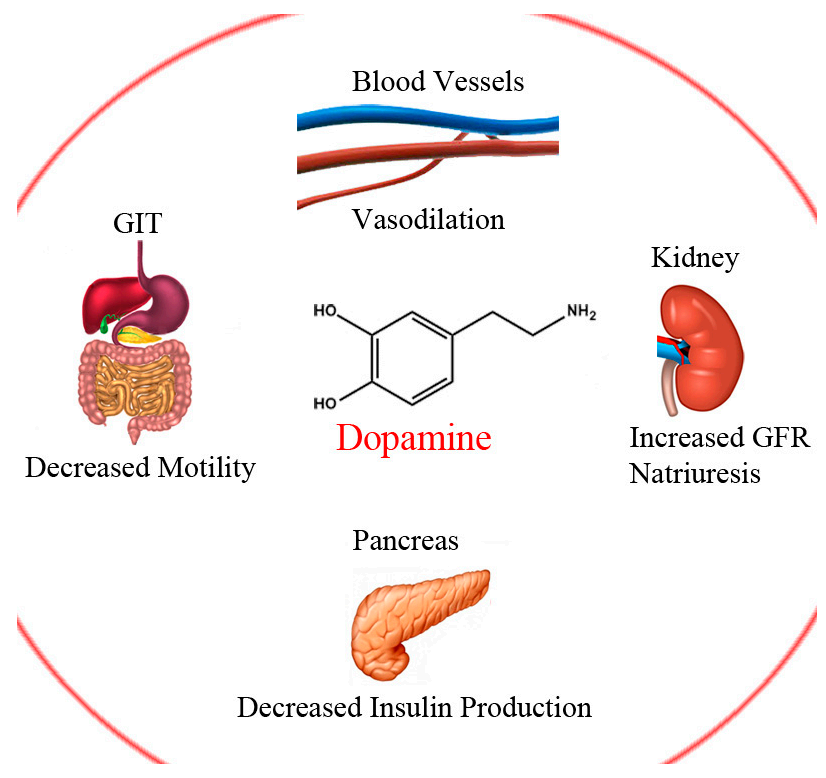

Figure 1. Select peripheral actions of dopamine. 
Pharmacologic treatment of PD is mainly symptomatic based on DA replacement therapy, as exogenous DA and other catecholamines cannot be administered due to their poor brain blood barrier (BBB) penetration [1]. There are a number of drugs available for the treatment of PD. These include agonists of dopamine (rotigotine, ropinirole, and lisuride), cholinesterase inhibitors (donepezil), antimuscarinic drugs (trihexyphenidyl, benztropine, biperiden), MAO-B inhibitors (selegiline, rasagiline), amantadine, and other DA and LD prodrugs [8,9].

However, administering external dopamine to PD patients as treatment is limited, as dopamine is a water-soluble hydrophilic drug that does not satisfy the characteristics of a substance that can enter the brain by BBB penetration $[1,10,11]$.

This penetration can be achieved by one of three main ways. First, a drug has to diffuse freely through the membrane if it obeys Lipinski's rule of five, suggested and applied since 1997 [12], with minor exceptions. Secondly, one which can permeate via active transport through specific carriers such as amino acid and nucleoside carriers. Thirdly, a drug or substance which can be internalised either by electrostatic interactions with specific endothelial membranes (adsorptive-mediated transport) or through receptor mediated endocytosis, as is the case as with proteins and peptides [13-16].

L-Dopa (LD), is the direct precursor of DA and is a suitable prodrug as it facilitates CNS penetration and delivers DA. It has been, and still is, considerably the golden standard therapy for PD especially in the early stages [17-19]. Nevertheless, chronic long-term treatment with LD causes motor complications (on-off phenomenon) in the majority of patients. In addition, dyskinesia may occur due to excess dopaminergic tone [20,21]. In the early stages of PD, LD is a very effective treatment of PD [18,19], particularly when given in combination with carbidopa, a decarboxylase inhibitor. Carbidopa works on the peripheral decarboxylase inhibitor and cannot pass the BBB; its role is to decrease the peripheral breakdown of $L D$, thus, mostly avoiding the drug's systemic side effects [22,23].

In normal brain tissue the basal ganglia maintains the brain's needs of DA for motor control and others, but LD oral administration has low bioavailability (10\% with only $1 \%$ of LD reaching the brain) due to erratic gastrointestinal metabolism of the drug before it attaches to the L-amino acid carrier that transports the drug actively through the duodenum where it enters the bloodstream intact [24-29]. Thus, lessened amounts of DA puts the brain under fluctuations that are hard to accommodate [30,31]. Other side effects may occur systemically, including cardiac arrhythmias, hypotension and vomiting as a result of peripheral LD metabolism [22,24]. Strategies to overcome these problems were established to ensure the presence of constant levels of DA in a PD patient's brain. One strategy was to inhibit LD breakdown in peripheral tissues, consequentially overcoming systemic side effects. Immediate release preparations of $\mathrm{LD}$ have a short $\mathrm{t}_{1}$ of 1-3 $\mathrm{h}$ [25], which can be prolonged by the inhibition of catechol-O-methyl transferase (COMT) through entacapone and tolcapone, or dopa-decarboxylase (DDC) through carbidopa. As a result, levels of LD reaching the BBB will be increased, therefore increasing their entrance and maintaining near normal levels of DA in the brain $[26,27,30,32]$.

Therefore, various strategies were applied to conquer CNS penetration. Direct administration of the drug into the brain, temporal interruption of the BBB, addition of chemical groups to the needed substance for enhancing its permeability (the prodrug approach) and formulation of carriers with lipophilic surfaces including liposomes, nanoparticles, dendrimers, as well as micelles [33,34]. In the last few decades, the use of the prodrug approach has gained increased interest. It includes editing the drug's physicochemical properties, through conjugation with another moiety for example, to overcome pharmacokinetic or pharmacodynamic hurdles, with the intention of releasing the parent drug post activation or degradation of the prodrug [11,35-38].

In this review, strategies employed in the synthesis of L-dopa and dopamine prodrugs are highlighted based on the type of prodrug synthesized. Those strategies can be classified as: ester, amide, dimeric amide, carrier-mediated, and cyclic prodrugs as well as chemical delivery systems and enzyme models. 


\subsection{Ester Prodrugs}

A widely applied and common strategy for prodrug synthesis is the use of esters [39-41]. By exploiting ester linkages, which are susceptible to both chemical and enzymatic hydrolysis, molecules can be synthesized with the aim of yielding the active pharmacological compound once the linkage is cleaved.

A series of promising LD ester prodrugs were previously synthesized in an attempt to increase the bioavailability of LD (1-9 in Figure 2) [42-48]. However, none of those demonstrated significantly longer duration of action or potency. XP21279 (10 in Figure 2) was a drug patented by Xenoport (later acquired by Arbor Pharmaceuticals, Atlanta, GA, USA). The drug held potential for sustained release formulations due to lower GI tract absorption. Originally it showed potential to reduce dopamine fluctuations and was expected to decrease "off time" dyskinesia. In a phase II trial [49] investigating XP21279-carbidopa combination, it was found that it could be administered 3 times daily, but failed to show marked reductions in off time.
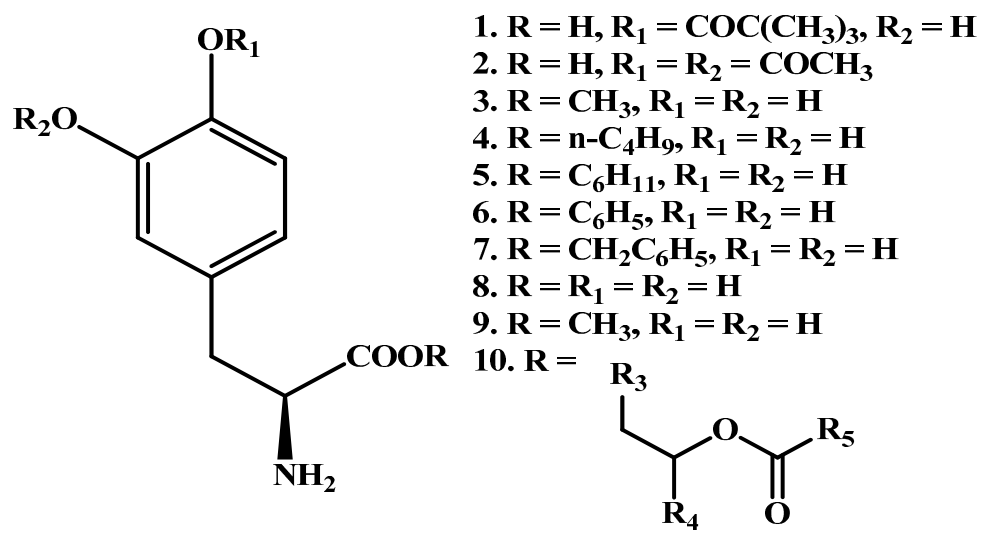

Figure 2. Chemical structures of LD ester prodrugs, 1-10.

Etilevodopa (TV 1203), an ethyl ester of LD was produced [50]. The prodrug was rapidly hydrolysed by esterases in the duodenum and absorbed as LD. Etilevodopa appeared to have increased solubility and bioavailability with shorter time to $\mathrm{C}_{\max }$. However, no marked improvement in on-off fluctuations in PD patients was recorded and hence the prodrug was dropped.

Casagrande et al. [51] and Borgman et al. [52] have prepared latentiated lipophilic derivatives of DA. The series of lipophilic 3,4-O-diesters (11-15 in Figure 3), are intended for use in the treatment of parkinsonism, hypertension and renal failure. Unfortunately, the results demonstrated that O-acetylation was not sufficient to allow penetration into CNS.

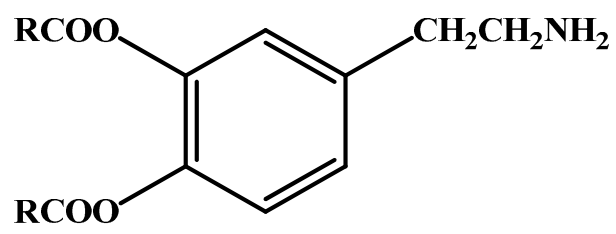
11. $\mathrm{R}=\mathrm{CH}_{3}-$
12. $\mathrm{R}=\mathrm{CH}\left(\mathrm{CH}_{3}\right)_{2}$
13. $\mathrm{R}=\mathrm{C}(\mathrm{CH3})_{3}-$
14. $\mathrm{R}=\mathrm{C}_{6} \mathrm{H}_{5}-$
15. $\mathrm{R}=\mathrm{C}_{2} \mathrm{H}_{5} \mathrm{O}-$

Figure 3. Chemical structures of lipophilic 3,4-O-diester prodrugs of DA, 11-15.

Also, nasal powder preparations of the prodrug, LD methyl ester hydrochloride (LDME) (3 in Figure 2), hold potential benefit for alternate routes of delivery with bioavailability figures reaching $66.7 \%$ and $82.4 \%$ with and without Carbopol, respectively [53]. Combining LD methyl ester hydrochloride with trans buccal delivery would be expected to have higher bioavailability than LD and be capable of maintaining better plasma levels of the drug [54]. LDME is currently in Phase III clinical trials and expected to be with decreased adverse effects [55]. 


\subsection{Amide Prodrugs}

In addition to the abovementioned ester prodrugs, amide prodrugs are also capable of increasing the lipophilicity of DA and hence, the ability to cross the BBB through passive diffusion, making them a logical option in LD prodrug synthesis. Though, and in contrast to esters, amides are less susceptible to hydrolysis. A general formula for potential amides is depicted in (16 in Figure 4) [56].

Jiang et al. [57] synthesized and tested an amide prodrug on rats ( $\mathbf{1 7}$ in Figure 4 ). In vivo study results showed enzymatic hydrolysis and release of LD after oral administration with $\mathrm{C}_{\max }$ being $1980.7 \pm 538.5$ vs. $1936.6 \pm 114.6 \mathrm{ng} / \mathrm{mL}, \mathrm{T}_{\max }$ was $24.5 \pm 3.5 \mathrm{vs} .4 .5 \pm 0.8 \mathrm{~min}$, AUC was $217,158.9 \pm$ $70,832.1$ vs. $94,469.5 \pm 7183.0 \mathrm{ng} / \mathrm{mL}$ min and the $\mathrm{t}_{\frac{1}{2}}$ was $56.5 \pm 14.4 \mathrm{vs}$. $30.6 \pm 1.6 \mathrm{~h}$ for the amide prodrug and L-dopa respectively.

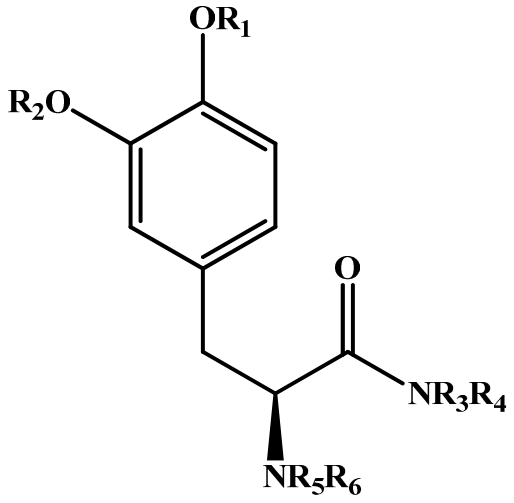

16

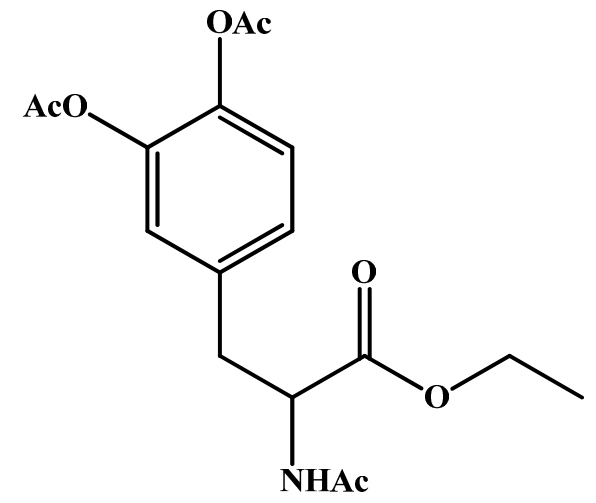

17

Figure 4. Chemical structures of general amide prodrugs (16) and (S)-4-(2-acetamido-3-ethoxy3-oxopropyl)-1,2-phenylene diacetate (17).

Zhou et al. [58] reported the synthesis of a series of new LD amides (L-dopamides, 18-33 in Figure 5) studied in unilaterally 6-hydroxydopamine (6-OHDA)-lesioned rats. The authors declared that less L-dopa was obtained from compounds with more hydrophobic ester protecting groups (structures 18-22) compared with acetyl compounds (structure 29). This is due to slower hydrolysis of amides when compared to hydrolysis-susceptible esters which exhibit poor plasma stability. Prodrug 29 showed the best results with prolonged duration of action (147 min) vs. LD (119 min), following oral administration.<smiles></smiles>

Figure 5. Chemical structures of a synthetic series of amide prodrugs, 18-33.

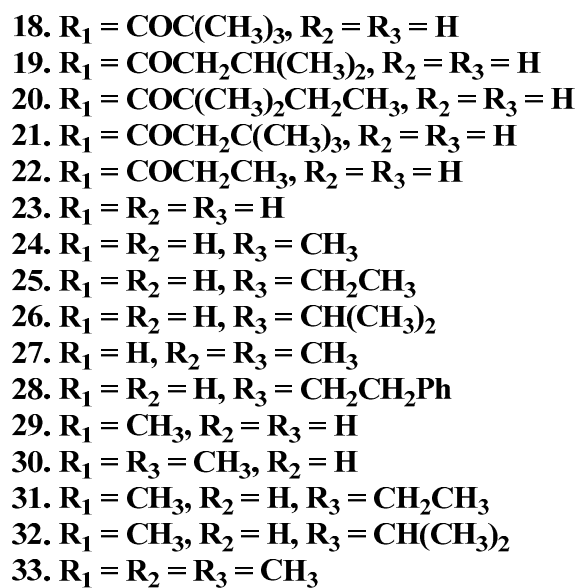


Denora et al. [59] proposed a series of novel amide LD prodrugs (Figure 6, 34-41), called Dopimid compounds. The series have high BBB penetrating potential due to substituted 2-phenyl-imidazopyridine-3-acetic acid. Of these Dopimid compounds, 34, 35, 38 and 39 were found to be stable against chemical hydrolysis, although they showed faster breakdown in diluted rat serum at $37^{\circ} \mathrm{C}$, and were able to penetrate the CNS. Moreover, a dose- and time-dependent elevation of DA levels in rat medial prefrontal cortex after intraperitoneal administration of compounds $\mathbf{3 8}$ and $\mathbf{3 9}$ was obtained. Similar results were also obtained by Eltayb et al. after i.p. administration of LD [60].

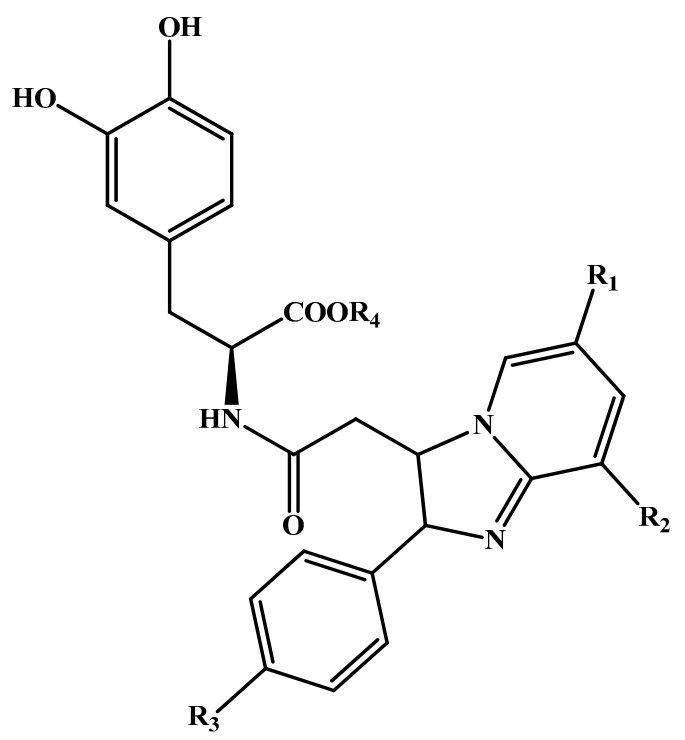

$$
\begin{aligned}
& \text { 34. } \mathbf{R}_{\mathbf{1}}=\mathbf{R}_{\mathbf{2}}=\mathbf{R}_{3}=\mathrm{Cl}, \mathbf{R}_{\mathbf{4}}=\mathrm{H} \\
& \text { 35. } \mathbf{R}_{1}=\mathbf{R}_{3}=\mathbf{C l}, \mathbf{R}_{2}=\mathbf{R}_{4}=\mathbf{H} \\
& \text { 36. } \mathbf{R}_{\mathbf{1}}=\mathbf{R}_{\mathbf{2}}=\mathrm{Cl}, \mathbf{R}_{\mathbf{3}}=\mathbf{R}_{\mathbf{4}}=\mathrm{H} \\
& \text { 37. } \mathbf{R}_{\mathbf{1}}=\mathbf{C l}, \mathbf{R}_{\mathbf{2}}=\mathbf{R}_{\mathbf{3}}=\mathbf{R}_{\mathbf{4}}=\mathbf{H} \\
& \text { 38. } \mathbf{R}_{1}=\mathbf{R}_{\mathbf{2}}=\mathbf{R}_{\mathbf{3}}=\mathrm{Cl}, \mathbf{R}_{\mathbf{4}}=\mathrm{CH}_{\mathbf{2}} \mathrm{CH}_{\mathbf{3}} \\
& \text { 39. } R_{1}=R_{3}=C l, R_{2}=H, R_{4}=C_{2} C_{2} H_{3} \\
& \text { 40. } \mathbf{R}_{1}=\mathbf{R}_{2}=\mathrm{Cl}, \mathrm{R}_{3}=\mathrm{H}, \mathrm{R}_{\mathbf{4}}=\mathrm{CH}_{2} \mathrm{CH}_{3} \\
& \text { 41. } R_{1}=C l, R_{2}=R_{3}=H, R_{4}=C_{2} C_{3}
\end{aligned}
$$

Figure 6. Chemical structures of substituted 2-phenyl-imidazopyridine-3-acetic acid amide prodrugs of LD.

\subsection{Dimeric Amide Prodrugs}

Dimeric prodrugs are, in essence, two identical molecules attached directly or indirectly using a spacer [61-65]. Felix and co-workers [66] have efficiently synthesized LD dimer prodrug without a spacer (42 in Figure 7). On the other hand, Stefano and co-workers have synthesized various LD dimers [67-70] with different spacers used for each molecule (43-50 in Figure 7).<smiles>CC(=O)[C@H](Cc1ccc(O)c(O)c1)NC(=O)[C@H](N)Cc1ccc(O)c(O)c1</smiles><smiles>[R]C[C@H](NC(=O)N[C@@H](C[R])C(C)=O)C(C)=O</smiles>

43<smiles>[R]C[C@H](NC(=O)C(=O)N[C@@H](C[R])C(C)=O)C(C)=O</smiles>

44

Figure 7. Cont. 
<smiles>[R]C[C@H](NC(=O)/C=C/C(=O)N[C@H](C[R])C(=O)OC)C(=O)OC</smiles>

45<smiles>[R]C[C@H](NC(=O)/C=C/C(=O)N[C@@H](C[R])C(C)=O)C(C)=O</smiles>

46<smiles>[R]C[C@H](NC(=O)O[14CH3])C(=O)N[C@@H](C[2H])C(=O)N[C@@H](C[2H])C(C)=O</smiles>
47. $\mathbf{n}=1$,
48. $n=2$,
49. $n=3$,
50. $n=4$

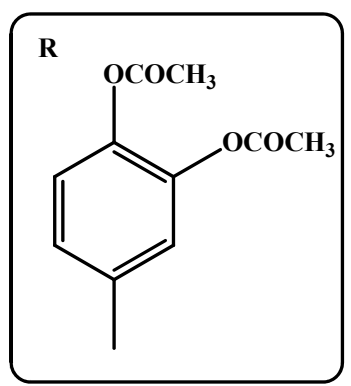

Figure 7. Chemical structures of dimeric amide prodrugs, 42-50.

All dimeric prodrugs made have shown stability in buffer solution ( $\mathrm{pH} 1.3$ and $\mathrm{pH} 7.4$ ), as well as a slow release of LD when tested in human plasma. Moreover, after oral administration of these compounds, the concentration of dopamine decreased much more slowly than that revealed with LD oral administration.

\subsection{Carrier-Mediated Prodrugs}

In this approach drugs are linked to an endogenous transporter substrate like amino acids, glucose, and other hexoses. This is aimed at the utilization of active transport mechanisms to ease BBB penetration, followed by bioconversion to yield the parent drug [35,71]. Most widely used transport systems in the prodrugs approach are glucose transporter (GLUT1), large neutral amino acid transporter (LAT1), monocarboxylic acid transporter (MCT) and peptide transport systems [72-75].

Novel DA glycosyl derivatives which can be transported by GLUT1 have been synthesized. Fernandez and co-workers [76,77] have synthesized glycosyl derivatives by attaching sugar and dopamine through a succinyl linker, carbamate bond, glyosidic, and ester bonds. They linked the amino group of DA to the C-6, C-3 and C-1 of the sugar through a succinyl linker (51-53, Figure 8) or a carbamate bond (compounds 54-56). In another series, the sugar was linked to the phenolic groups of dopamine through a glyosidic bond (59 and 60) and ester (61-63) bonds, and then the affinity of these prodrugs for glucose carrier GLUT1 was tested using human erythrocytes. When DA-glycoconjugates were incubated with the brain extracts, the nature of the bond attaching DA with glucose affected the rate of DA release. The glycosyl conjugates substituted at the C-6 position of the sugar were more potent inhibitors of glucose transport in contrast to C-1 and C-3 substituted prodrugs. Among the studied compounds, the carbamate derivatives 52, 56 and 57 were the prodrugs of choice, in particular compound 54, which showed the best affinity for GLUT1, even higher than glucose itself. 
<smiles>[R]NCCc1ccc([R20])c([R20])c1</smiles>

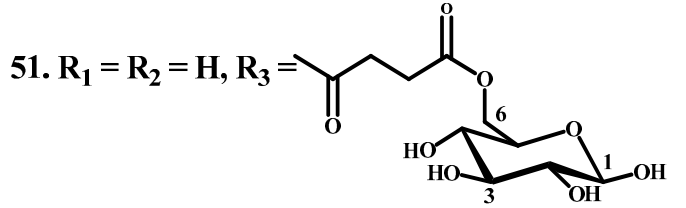

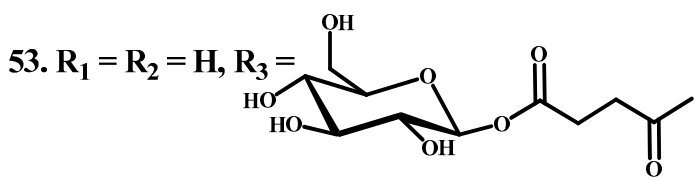<smiles>[R15]C=[R16]=[Sb]</smiles>

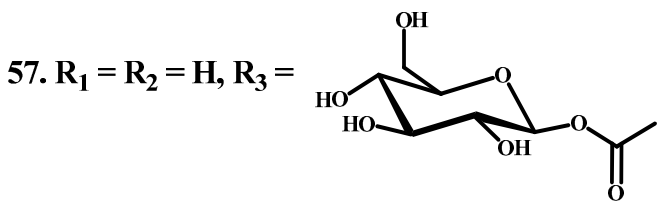
59. $R_{2}=R_{3}=H, R_{1}=$

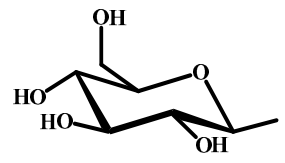

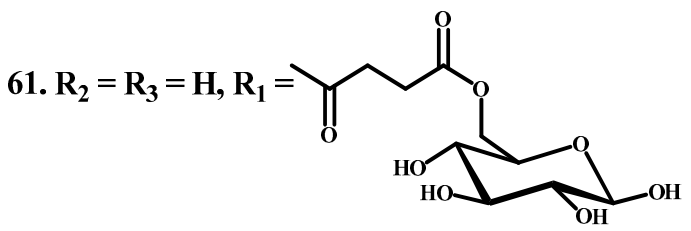

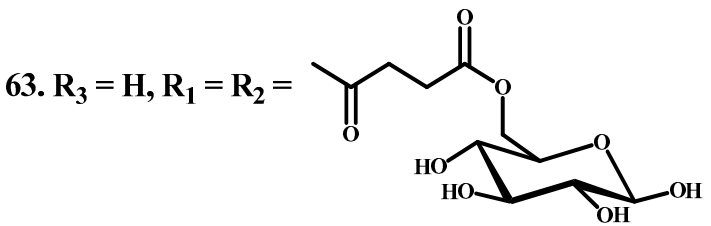

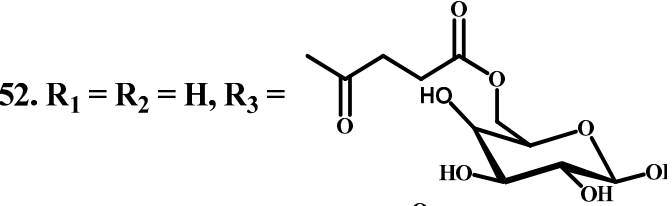
54. $\mathbf{R}_{\mathbf{1}}=\mathbf{R}_{\mathbf{2}}=\mathrm{H}, \mathbf{R}_{\mathbf{3}}=$

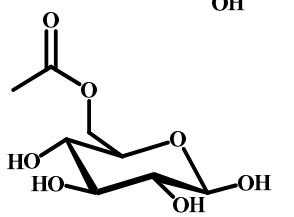
56. $\mathbf{R}_{\mathbf{1}}=\mathrm{R}_{\mathbf{2}}=\mathrm{H}, \mathrm{R}_{\mathbf{3}}=$

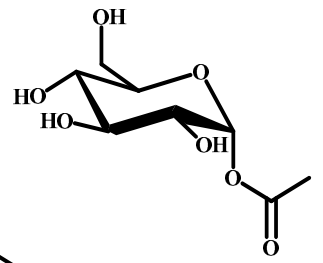
58. $\mathbf{R}_{\mathbf{1}}=\mathbf{R}_{\mathbf{2}}=\mathbf{H}, \mathbf{R}_{\mathbf{3}}=$

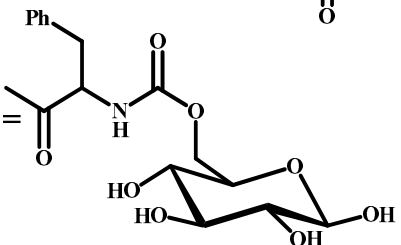

60. $R_{1}=R_{3}=H, R_{2}=$

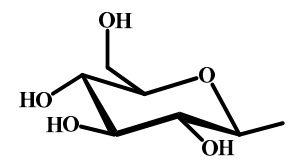

62. $R_{1}=R_{3}=H, R_{2}=\prod_{O}$

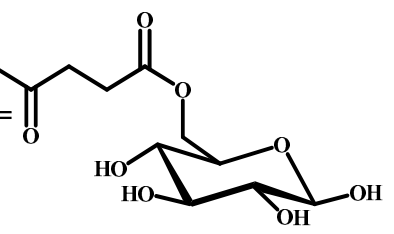

Figure 8. Glycosyl DA derivatives, 51-63.

In another study, Bonina et al. and Ruocco et al. $[78,79]$ have prepared sugar-DA prodrugs in which DA was attached to the C-3 position of glucose (64 in Figure 9) and to C-6 of galactose (65 in Figure 9 ) by a succinyl spacer. Pharmacological studies showed that both prodrugs were more active than $\mathrm{LD}$ in reversing reserpine-induced hypolocomotion in rats. 

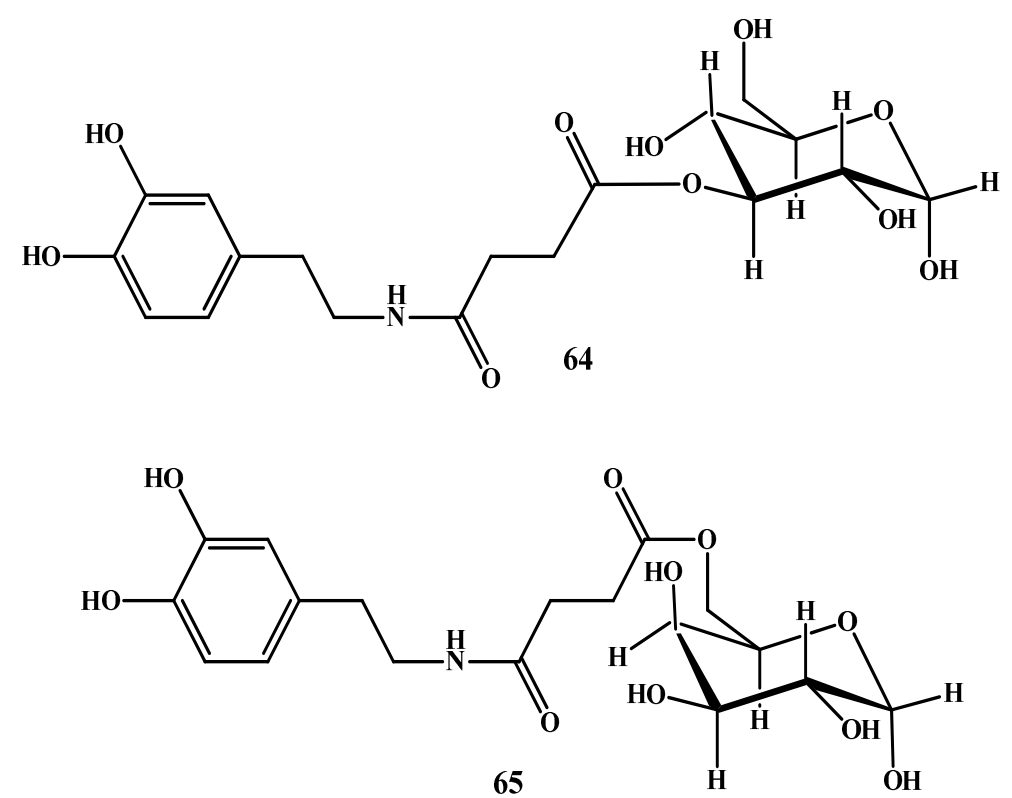

Figure 9. Chemical structures of glycosuccinyl-derivatives of DA, 64 and 65.

\subsection{Peptide Transport-Mediated Prodrugs}

Giannola et al. [80] have proposed a 2-amino-N-[2-(3,4-dihydroxyphenyl)-ethyl]-3phenyl-propionamide dopamine prodrug (DA-PHEN) (Figure 10) [81]. It was synthesized by condensation of dopamine with a neutral amino acid to interact with the BBB endogenous transporters and readily enter the CNS. DA-PHEN undergoes slow cleavage by cerebral enzymes ( $\left.t_{\frac{1}{2}} 460 \mathrm{~min}\right)$ and yields free dopamine in the brain, but it is rapidly hydrolyzed in human plasma $\left(t_{\frac{1}{2}}^{2} 28 \mathrm{~min}\right)$. Chemical stability studies on DA-PHEN proved that no DA release happened in the gastrointestinal tract, also the prodrug can cross through a simulated intestinal mucosal membrane.

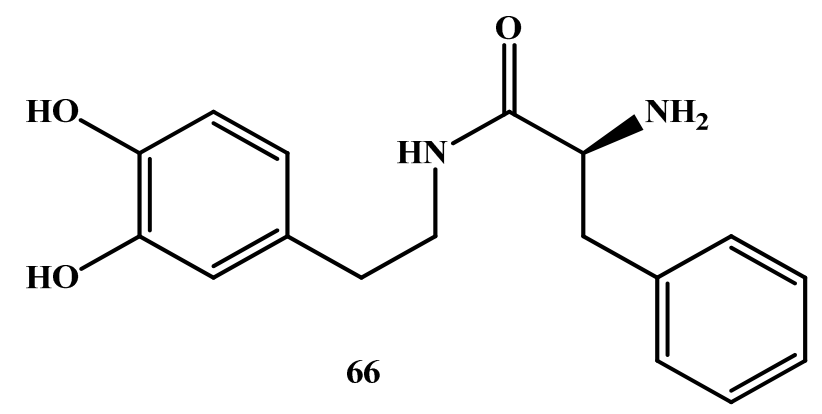

Figure 10. Structure of 2-amino- $N$-[2-(3,4-dihydroxy-phenyl)-ethyl]-3-phenylpropionamide (DA-PHEN), 66.

Recently, De Caro et al. [81] studied in vitro the ability of DA-PHEN to penetrate the CNS. The team used in their study parallel artificial permeability assay (PAMPA) and Caco-2 models. Despite the relatively low molecular weight (300.35 Da) and the estimated experimental value [80] of $\log \mathrm{D}_{\mathrm{Ph}} 7.4$ (0.76) of DA-PHEN which indicates good potential for passage through biological membranes, they noticed very limited transport through PAMPA-BBB [81]. In fact, the apparent permeability was $3.2 \times 10^{7} \mathrm{~cm} / \mathrm{s}$, indicating low capacity of DA-PHEN to penetrate BBB by passive transcellular route. Transport trials via Caco-2 cells showed marked increase of DA-PHEN flux with regard to that calculated in PAMPA-BBB system. However, high penetration rates seen in DA-PHEN cannot be obtained only by the simple diffusion, but may also involve carrier mediated transport [82]. 
In another study, More and Vince [83] focused on the glutathione uptake transporters that are located on the luminal side of the BBB in attempt to increase BBB penetration of dopamine. The broad substrate specificity displayed by these transporters provides ample opportunity for rational prodrug design. The design of glutathione transporter targeted prodrug involved three components: the carrier, glutathione (GSH), the active drug, and a suitable linker for conjugation of the carrier with the drug molecule. The prodrug 67 (Figure 11) in which the dopamine is covalently linked via an amide bond to glutathione (GSH) demonstrated a high affinity for the GSH transporter at the BBB, liberated dopamine at the active site, and showed good stability balance between the periphery and brain.<smiles>N[C@@H](CNC(=O)N[C@@H](CSSCC(=O)C(=O)NCCc1ccc(O)c(O)c1)C(=O)NCC(=O)O)C(=O)O</smiles>

Figure 11. Glutathione conjugated prodrug of dopamine, 67.

\subsection{Chemical Delivery Systems}

Ishikura and co-workers synthesized LD prodrugs by an esterification of LD carboxylic acid with a thiazolium moiety [84]. Four novel compounds were made (Figure 12). Ishikura and his team's novel compounds rely on redox ring closure reactions of cis-2 formylaminoethenylthio derivatives to quaternary thiazolium derivatives and LD liberation after hydrolysis of the ester bond, as illustrated in (Scheme 2). The disposition of the prodrugs was evaluated by measuring the concentrations of DA regenerated after intravenous administration of the prodrugs and the results were compared with those for LD itself. The plasma levels of DA demonstrated no significant differences between DA and the prodrugs. In contrast, however, brain levels of DA were remarkably elevated following administration of the prodrugs. These findings suggest that a redox ring-closure system to a quaternary thiazolium can be used as an alternative chemical delivery system to the brain.

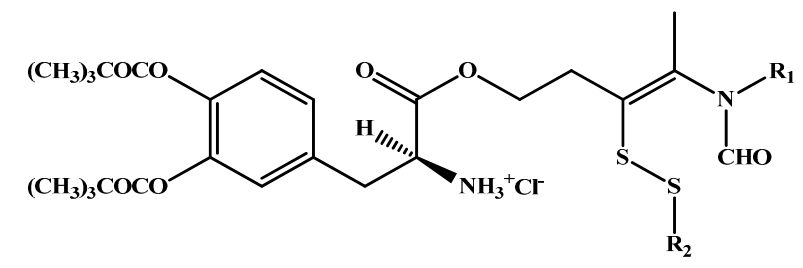

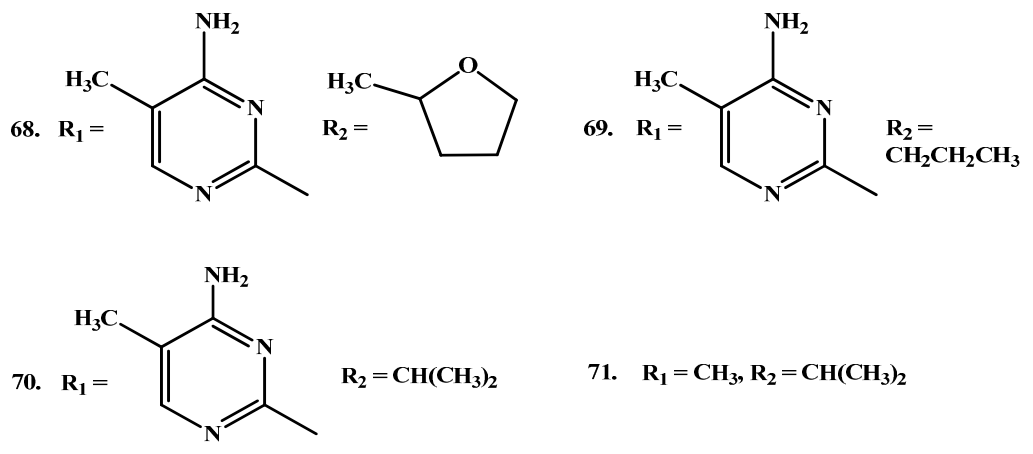

Figure 12. Chemical structures of carboxylic acid-thiazolium prodrugs of LD, 68-71. 


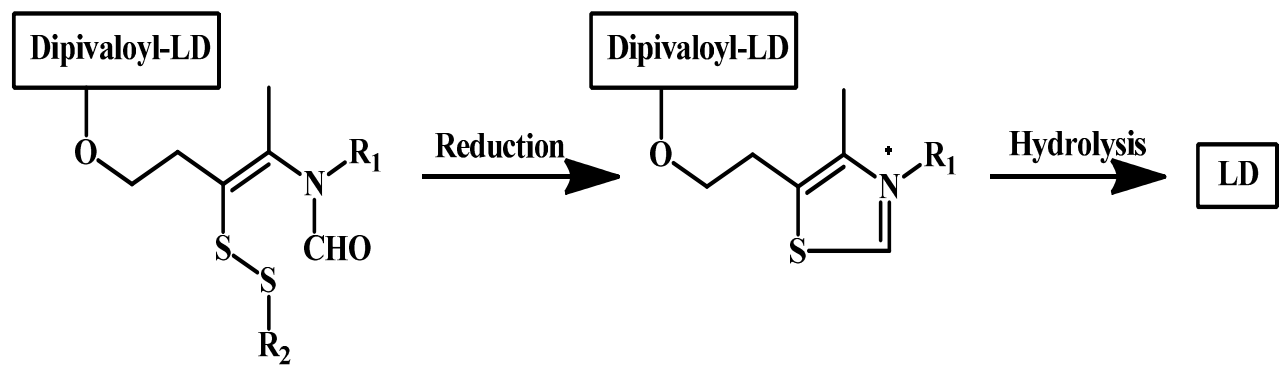

Scheme 2. Activation mechanism of carboxylic acid-thiazolium prodrugs of LD.

\subsection{Cyclic Prodrugs}

Cingolani and co-workers [85] have prepared 1-3-(3-hydroxy-4-pivaloyloxybenzyl)-2,5diketomorpholine ring (Figure 13), to enhance the stability toward GI hydrolysis and to liberate LD in human plasma after enzyme-catalysed hydrolysis. Further, Giorgioni et al. [86,87] synthesized three cyclic compounds through the introduction of LD functional groups into animidazoline-4-one ring. The use of this ring particularly was based on its previously assured efficiency in protecting enkephalins from aminopeptidase degradation. The cyclic compounds were sufficiently stable in the acidic environment of the stomach; their absorption occurred in the intestine, and were capable to release LD to the brain in a slow manner.<smiles>CC(=O)Oc1ccc(C[C@H]2NC(=O)COC2=O)cc1O</smiles><smiles>[R20]Oc1ccc(C[C@@H]2NC([R1])([R4])N(CC(=O)OC)C2=O)cc1[R20]</smiles>

Figure 13. Chemical structures of cyclic prodrugs of LD, 73-75.

\subsection{Enzyme Model (Intramolecular Processes)}

Despite some success that has been achieved using derivatives of DA and LD to supply DAin adequate concentrations and sustained release manner, the prodrugs chemical approach requiring enzyme catalysis has many limitations including many intrinsic and extrinsic factors that can alter the process. For example, the efficiency of many prodrug-activating enzymes may be different according to age-related physiological changes, drug interactions, or genetic polymorphisms, causing variation in clinical activity. Therefore, new derivatives for treatment of PD with drugs having higher bioavailability than the existing medications, and with the ability to liberate dopamine in a sustained fashion through chemical conversion without a need for enzyme catalysis is crucially needed [88].

In the past ten years, Karaman's group have utilized molecular orbital methods such as ab initio and density functional theory (DFT) for the design of a large number of prodrugs which have 
the potential to undergo intramolecular cleavage to furnish the parent drugs and non-toxic linkers. The cleavage inintramolecular chemical rate is solely dependent on the nature of the linker and the physiologic environment to which the prodrug is exposed.

Among others, they designed and synthesized a number of DA prodrugs to be used in the treatment of Parkinson's disease with higher bioavailability than the existing medications. The synthesized prodrugs have moderate hydrophilic lipophilic balancewhich is important for their absorption and distribution [89], are soluble in physiological environment, their linkers are non-toxic, and have the potential to release DA in a sustained release manner (76-77 in Figure 14). Kinetics study on 76 revealed that the prodrug was intraconverted to DA with $t_{1}$ values of $60.3,54.66,99.93$ and $138.13 \mathrm{~h}$ in $0.1 \mathrm{~N} \mathrm{HCl}$, buffer $\mathrm{pH} 2.2$, buffer $\mathrm{pH} 5.5$ and buffer $\mathrm{pH} 7.4^{2}$, respectively. On the other hand, prodrug 77 was readily converted in $0.1 \mathrm{~N} \mathrm{HCl}$, buffer $\mathrm{pH} 2.2, \mathrm{pH} 5.5$ and $\mathrm{pH} 7.4$ with $\mathrm{t}_{\frac{1}{2}}$ values of $48.34,54.22,131.98$ and $193.42 \mathrm{~h}$, respectively. The in silico and in vivo (rat) results demonstrated that both prodrugs are tolerable with low toxicity.

In vivo pharmacokinetics study is underway and it is believed that an oral enteric coated dosage form (to avoid conversion in acidic medium) will give pharmacokinetics profile with improved bioavailability than the current marketed drug [83-86].<smiles>O=C(O)C1CCCCC1C(=O)NCCc1ccc(O)c(O)c1</smiles>

76<smiles>CC1CCC(C(=O)NCCc2ccc(O)c(O)c2)C(C(=O)O)C1</smiles>

Figure 14. Chemical structures of DA prodrugs 76 and 77.

\section{Summary and Conclusions}

Till today, PD treatments were based mostly on exogenous dopamine substitution within the striatum and LD is still the drug of choice to manage symptoms of PD. However, long-term therapy with L-dopa is associated with significant side effects. The main challenge in improving LD therapy is to reduce or remove the motor complications created or aggravated by noticeable LD plasma circulating level fluctuations.

Dopamine and LD provide several sites in their chemical structures where it is possible to perform chemical alteration, this helped to have derivatives with enhanced physicochemical characteristics. In the past few years, researchers have conveyed their awareness towards designing targeted dopamine and LD prodrugs to replace exciting marketed drugs which have poor physicochemical and pharmacological properties. As mentioned above, dopamine and LD prodrugs should be soluble in both water and lipid, fully absorbed by gastrointestinal tract without any chemical degradation or metabolism, and have the ability to cross the BBB and hence to produce dopamine at the brain at consistent therapeutic level. Furthermore, an ideal prodrug should have sufficient and constant 
plasmatic levels to be able to provide continuous dopaminergic stimulation, thus preventing the manifestation and severity of LD-induced motor fluctuations and dyskinesia.

There is promising data regarding using prodrugs for the treatment of PD. For example, ester prodrugs of LD have demonstrated to be suitable for intranasal delivery of LD [42,90]. This approach is considered as one of the administration routes that appear to enable the absorption of therapeutic agents to the brain bypassing the limitations of the BBB; most of the amide, cyclic, peptidyl or chemical delivery systems of DA prodrugs haveshown decreased enzymatic and hydrolytic susceptibility together with enhanced pharmacokinetic properties.

A promising and interesting approach suggested by Karaman's group to overcome the limitation of the existing targeting prodrugs is model in which a parent drug is connected to enzyme model (intramolecular chemical device) and when the prodrug reaches the blood circulation within CNS, it undergoes intramolecular chemical conversion-without any regiment of enzyme allowing the active parent drug to be released in a sustained manner. The conversion rate of the prodrug to its parent drug is solely determined on the chemical features of the linker (enzyme model). This approach has the potential to, provide effective drug delivery system having selective targeting of DA and LD prodrugs to the striatum.

Acknowledgments: The authors would like to thank the Deanship of Scientific Research at Al-Quds University for covering the publication fees for this review article.

Conflicts of Interest: The authors of this review have no conflict of interest to declare.

\section{Abbreviations}

$\begin{array}{ll}\text { PD } & \text { Parkinson's disease } \\ \text { DA } & \text { Dopamine } \\ \text { LD } & \text { LevoDopa } \\ \text { BBB } & \text { Blood brain barrier } \\ \text { CNS } & \text { Central nervous system } \\ \text { AUC } & \text { Area under the curve } \\ \text { 6-OHDA } & \text { 6-hydroxydopamine } \\ \text { i.p. } & \text { Intraperitoneal } \\ \text { COMT } & \text { Catechol-O-methyltransferase } \\ \text { DDC } & \text { Dopa-decarboxylase } \\ \text { MAO } & \text { Mono amino oxidase } \\ \text { GSH } & \text { Glutathione } \\ \text { DA-PHEN } & \text { 2-Amino- } N \text {-[2-(3,4-dihydroxy-phenyl)-ethyl]-3-phenyl-propionamide } \\ \text { PAMPA } & \text { parallel artificial permeability assay } \\ \text { GLUT1 } & \text { glucose transporter } \\ \text { MCT } & \text { monocarboxylic acid transporter } \\ \text { PDDP } & \text { dopamine-3-(dimethylamino) propanamide } \\ \text { LAT1 } & \text { large neutral amino acid transporter }\end{array}$

\section{References}

1. Iversen, L.L. Dopamine Handbook; Oxford University Press: Cary, NC, USA, 2010.

2. Daubner, S.C.; Le, T.; Wang, S. Tyrosine hydroxylase and regulation of dopamine synthesis. Arch. Biochem. Biophys. 2011, 508, 1-12. [CrossRef] [PubMed]

3. Shastry, B.S. Parkinson disease: Etiology, pathogenesis and future of gene therapy. Neurosci. Res. 2001, 41, 5-12. [CrossRef]

4. Abou-Sleiman, P.M.; Muqit, M.M.; Wood, N.W. Expanding insights of mitochondrial dysfunction in Parkinson's disease. Nat. Rev. Neurosci. 2006, 7, 207-219. [CrossRef] [PubMed]

5. De Lau, L.M.; Breteler, M.M. Epidemiology of Parkinson's disease. Lancet Neurol. 2006, 5, 525-535. [CrossRef]

6. Spillantini, M.G.; Schmidt, M.L.; Lee, V.M.-Y.; Trojanowski, J.Q.; Jakes, R.; Goedert, M. A-synuclein in lewy bodies. Nature 1997, 388, 839-840. [CrossRef] [PubMed] 
7. Martin, L.J.; Pan, Y.; Price, A.C.; Sterling, W.; Copeland, N.G.; Jenkins, N.A.; Price, D.L.; Lee, M.K. Parkinson's disease $\alpha$-synuclein transgenic mice develop neuronal mitochondrial degeneration and cell death. J. Neurosci. 2006, 26, 41-50. [CrossRef] [PubMed]

8. Senek, M.; Nyholm, D. Continuous drug delivery in Parkinson's disease. CNS Drugs 2014, 28, 19-27. [CrossRef] [PubMed]

9. Di Stefano, A.; Sozio, P.; Iannitelli, A.; Cerasa, L.S. New drug delivery strategies for improved Parkinson's disease therapy. Expert Opin. Drug Deliv. 2009, 6, 389-404. [CrossRef] [PubMed]

10. Melamed, E.; Hefti, F.; Wurtman, R.J. Nonaminergic striatal neurons convert exogenous L-dopa to dopamine in Parkinsonism. Ann. Neurol. 1980, 8, 558-563. [CrossRef] [PubMed]

11. Rautio, J.; Kumpulainen, H.; Heimbach, T.; Oliyai, R.; Oh, D.; Järvinen, T.; Savolainen, J. Prodrugs: Design and clinical applications. Nat. Rev. Drug Discov. 2008, 7, 255-270. [CrossRef] [PubMed]

12. Lipinski, C.; Lombardo, F.; Dominy, B.; Feeney, P. Toward minimalistic modeling of oral drug absorption. Adv. Drug Deliv. Rev. 1997, 23, 3-25. [CrossRef]

13. Begley, D.J.; Brightman, M.W. Structural and functional aspects of the blood-brain barrier. In Peptide Transport and Delivery into the Central Nervous System; Springer: Berlin, Germany, 2003; pp. 39-78.

14. Pardridge, W.M. Blood-brain barrier drug targeting: The future of brain drug development. Mol. Interv. 2003, 3, 90-105. [CrossRef] [PubMed]

15. Abbott, N.J.; Rönnbäck, L.; Hansson, E. Astrocyte-endothelial interactions at the blood-brain barrier. Nat. Rev. Neurosci. 2006, 7, 41-53. [CrossRef] [PubMed]

16. Malakoutikhah, M.; Teixidó, M.; Giralt, E. Shuttle-mediated drug delivery to the brain. Angew. Chem. Int. Ed. 2011, 50, 7998-8014. [CrossRef] [PubMed]

17. Blandini, F.; Greenamyre, J.T. Protective and symptomatic strategies for therapy of Parkinson's disease. Drugs Today 1999, 35, 473-483. [CrossRef] [PubMed]

18. Group, P.S. Levodopa and the progression of Parkinson's disease. N. Engl. J. Med. 2004, 2004, 2498-2508.

19. Olanow, C.W.; Stern, M.B.; Sethi, K. The scientific and clinical basis for the treatment of Parkinson disease (2009). Neurology 2009, 72, S1-S136. [CrossRef] [PubMed]

20. Ahlskog, J.E.; Muenter, M.D. Frequency of levodopa-related dyskinesias and motor fluctuations as estimated from the cumulative literature. Mov. Disord. 2001, 16, 448-458. [CrossRef] [PubMed]

21. Porras, G.; De Deurwaerdere, P.; Li, Q.; Marti, M.; Morgenstern, R.; Sohr, R.; Bezard, E.; Morari, M.; Meissner, W.G. L-Dopa-induced dyskinesia: Beyond an excessive dopamine tone in the striatum. Sci. Rep. 2014, 4, 3730. [CrossRef] [PubMed]

22. Hagan, J.J.; Middlemiss, D.N.; Sharpe, P.C.; Poste, G.H. Parkinson's disease: Prospects for improved drug therapy. Trends Pharmacol. Sci. 1997, 18, 156-163. [CrossRef]

23. Nutt, J.G.; Woodward, W.R.; Anderson, J.L. The effect of carbidopa on the pharmacokinetics of intravenously administered levodopa: The mechanism of action in the treatment of Parkinsonism. Ann. Neurol. 1985, 18, 537-543. [CrossRef] [PubMed]

24. Standaert, D.G.; Young, A.B. Treatment of central nervous system degenerative disorders. In The Pharmacological Basis of Therapeutics, IXth ed.; Hardman, J.G., Limbrid, L.E., Eds.; McGraw-Hill: New York, NY, USA, 1996; pp. 503-519.

25. LeWitt, P.A. Levodopa for the treatment of Parkinson's disease. N. Engl. J. Med. 2008, 359, $2468-2476$. [CrossRef] [PubMed]

26. Nutt, J.; Woodward, W.; Beckner, R.; Stone, C.; Berggren, K.; Carter, J.; Gancher, S.; Hammerstad, J.; Gordin, A. Effect of peripheral catechol-O-methyltransferase inhibition on the pharmacokinetics and pharmacodynamics of levodopa in Parkinsonian patients. Neurology 1994, 44, 913. [CrossRef] [PubMed]

27. Nutt, J.G. Effect of COMT inhibition on the pharmacokinetics and pharmacodynamics of levodopa in Parkinsonian patients. Neurology 1999, 55, S33-S37, discussion S38-S41.

28. Kurlan, R.; Rothfield, K.; Woodward, W.; Nutt, J.; Miller, C.; Lichter, D.; Shoulson, I. Erratic gastric emptying of levodopa may cause "random" fluctuations of Parkinsonian mobility. Neurology 1988, 38, 419. [CrossRef] [PubMed]

29. Djaldetti, R.; Baron, J.; Ziv, I.; Melamed, E. Gastric emptying in Parkinson's disease patients with and without response fluctuations. Neurology 1996, 46, 1051-1054. [CrossRef] [PubMed]

30. Olanow, C.W. The scientific basis for the current treatment of Parkinson's disease. Annu. Rev. Med. 2004, 55, 41-60. [CrossRef] [PubMed] 
31. Olanow, C.W.; Obeso, J.A.; Stocchi, F. Continuous dopamine-receptor treatment of Parkinson's disease: Scientific rationale and clinical implications. Lancet Neurol. 2006, 5, 677-687. [CrossRef]

32. Brooks, D.J. Optimizing levodopa therapy for Parkinson's disease with levodopa/carbidopa/entacapone: Implications from a clinical and patient perspective. Neuropsychiatr. Dis. Treat. 2008, 4, 39-47. [CrossRef] [PubMed]

33. Denora, N.; Trapani, A.; Laquintana, V.; Lopedota, A.; Trapani, G. Recent advances in medicinal chemistry and pharmaceutical technology-strategies for drug delivery to the brain. Curr. Top. Med. Chem. 2009, 9, 182-196. [CrossRef] [PubMed]

34. Di Stefano, A.; Sozio, P.; Serafina Cerasa, L.; Iannitelli, A. L-Dopa prodrugs: An overview of trends for improving Parkinson's disease treatment. Curr. Pharm. Des. 2011, 17, 3482-3493. [CrossRef] [PubMed]

35. Rautio, J.; Laine, K.; Gynther, M.; Savolainen, J. Prodrug approaches for CNS delivery. AAPS J. 2008, 10, 92-102. [CrossRef] [PubMed]

36. Hsieh, P.-W.; Hung, C.-F.; Fang, J.-Y. Current prodrug design for drug discovery. Curr. Pharm. Des. 2009, 15, 2236-2250. [CrossRef] [PubMed]

37. Sozio, P.; Cerasa, L.S.; Abbadessa, A.; Di Stefano, A. Designing prodrugs for the treatment of Parkinson's disease. Expert Opin. Drug Discov. 2012, 7, 385-406. [CrossRef] [PubMed]

38. Freitas, M.E.; Ruiz-Lopez, M.; Fox, S.H. Novel levodopa formulations for Parkinson's disease. CNS Drugs 2016, 30, 1079-1095. [CrossRef] [PubMed]

39. Sinokrot, H.; Smerat, T.; Najjar, A.; Karaman, R. Advanced prodrug strategies in nucleoside and non-nucleoside antiviral agents: A review of the recent five years. Molecules 2017, 22, 1736. [CrossRef] [PubMed]

40. Ortiz de Montellano, P.R. Cytochrome p450-activated prodrugs. Future Med. Chem. 2013, 5, $213-228$. [CrossRef] [PubMed]

41. Krecmerova, M. Amino acid ester prodrugs of nucleoside and nucleotide antivirals. Mini Rev. Med. Chem. 2017, 17, 818-833. [CrossRef] [PubMed]

42. Kao, H.D.; Traboulsi, A.; Itoh, S.; Dittert, L.; Hussain, A. Enhancement of the systemic and CNS specific delivery of L-dopa by the nasal administration of its water soluble prodrugs. Pharm. Res. 2000, 17, 978-984. [CrossRef] [PubMed]

43. Bodor, N.; Sloan, K.B.; Higuchi, T.; Sasahara, K. Improved delivery through biological membranes. 4. Prodrugs of L-dopa. J. Med. Chem. 1977, 20, 1435-1445. [CrossRef] [PubMed]

44. Cooper, D.; Marrel, C.; Waterbeemd, H.; Testa, B.; Jenner, P.; Marsden, C. L-Dopa esters as potential prodrugs: Behavioural activity in experimental models of Parkinson's disease. J. Pharm. Pharmacol. 1987, 39, 627-635. [CrossRef] [PubMed]

45. Garzon-Aburbeh, A.; Poupaert, J.H.; Claesen, M.; Dumont, P. A lymphotropic prodrug of L-dopa: Synthesis, pharmacological properties and pharmacokinetic behavior of 1, 3-dihexadecanoyl-2-[(S)-2-amino-3-(3, 4-dihydroxyphenyl) propanoyl] propane-1, 2, 3-triol. J. Med. Chem. 1986, 29, 687-691. [CrossRef] [PubMed]

46. Cooper, D.; Marrel, C.; Waterbeemd, H.; Testa, B.; Jenner, P.; Marsden, C. L-Dopa esters as potential prodrugs: Effect on brain concentration of dopamine metabolites in reserpinized mice. J. Pharm. Pharmacol. 1987, 39, 809-818. [CrossRef] [PubMed]

47. Ihara, M.; Tsuchiya, Y.; Sawasaki, Y.; Hisaka, A.; Takehana, H.; Tomimoto, K.; Yano, M. A new potential prodrug to improve the duration of L-dopa: L-3-(3-hydroxy-4-pivaloyloxyphenyl)alanine. J. Pharm. Sci. 1989, 78, 525-529. [CrossRef] [PubMed]

48. Ihara, M.; Nakajima, S.; Hisaka, A.; Tsuchiya, Y.; Sakuma, Y.; Suzuki, H.; Kitani, K.; Yano, M. Hydrolysis and acyl migration of a catechol monoester of L-dopa: L-3-(3-hydroxy-4-pivaloyloxyphenyl) alanine. J. Pharm. Sci. 1990, 79, 703-708. [CrossRef] [PubMed]

49. LeWitt, P.A.; Huff, F.J.; Hauser, R.A.; Chen, D.; Lissin, D.; Zomorodi, K.; Cundy, K.C. Double-blind study of the actively transported levodopa prodrug xp21279 in Parkinson's disease. Mov. Disord. 2014, 29, 75-82. [CrossRef] [PubMed]

50. Djaldetti, R.; Giladi, N.; Hassin-Baer, S.; Shabtai, H.; Melamed, E. Pharmacokinetics of etilevodopa compared to levodopa in patients with Parkinson's disease: An open-label, randomized, crossover study. Clin. Neuropharmacol. 2003, 26, 322-326. [CrossRef] [PubMed]

51. Casagrande, C.; Ferrari, G. 3, 4-0-diacyl derivatives of dopamine. Farmaco Sci. 1973, 28, 143-148. [PubMed] 
52. Borgman, R.J.; McPhillips, J.J.; Stitzel, R.E.; Goodman, I.J. Synthesis and pharmacology of centrally acting dopamine derivatives and analogs in relation to Parkinson's disease. J. Med. Chem. 1973, 16, 630-633. [CrossRef] [PubMed]

53. Lee, Y.H.; Kim, K.H.; Yoon, I.K.; Lee, K.E.; Chun, I.K.; Rhie, J.Y.; Gwak, H.S. Pharmacokinetic evaluation of formulated levodopa methyl ester nasal delivery systems. Eur. J. Drug Metab. Pharmacokineti. 2014, 39, 237-242. [CrossRef] [PubMed]

54. Scaturro, A.L.; De Caro, V.; Campisi, G.; Giannola, L.I. Potential transbuccal delivery of L-dopa methylester prodrug: Stability in the environment of the oral cavity and ability to cross the mucosal tissue. Drug Deliv. 2016, 23, 2355-2362. [CrossRef] [PubMed]

55. Djaldetti, R.; Melamed, E. Levodopa ethylester: A novel rescue therapy for response fluctuations in Parkinson's disease. Ann. Neurol. 1996, 39, 400-404. [CrossRef] [PubMed]

56. Atlas, D. L-Dopa Amide Derivatives and Uses Thereof. U.S. Patent WO2004069146 A2, 19 Aug 2004.

57. Jiang, W.; Lv, L.; Zhou, S.; Huang, X.; Shi, X.; Lv, C.; Wu, L.; Xu, C. Simultaneous determination of L-dopa and its prodrug (S)-4-(2-acetamido-3-ethoxy-3-oxopropyl)-1, 2-phenylene diacetate in rat plasma by high-performance liquid chromatography-tandem mass spectrometry and its application in a pharmacokinetic study. J. Pharm. Biomed. Anal. 2010, 53, 751-754. [CrossRef] [PubMed]

58. Zhou, T.; Hider, R.C.; Jenner, P.; Campbell, B.; Hobbs, C.J.; Rose, S.; Jairaj, M.; Tayarani-Binazir, K.A.; Syme, A. Design, synthesis and biological evaluation of L-dopa amide derivatives as potential prodrugs for the treatment of Parkinson's disease. Eur. J. Med. Chem. 2010, 45, 4035-4042. [CrossRef] [PubMed]

59. Denora, N.; Laquintana, V.; Lopedota, A.; Serra, M.; Dazzi, L.; Biggio, G.; Pal, D.; Mitra, A.K.; Latrofa, A.; Trapani, G.; et al. Novel L-dopa and dopamine prodrugs containing a 2-phenyl-imidazopyridine moiety. Pharm. Res. 2007, 24, 1309-1324. [CrossRef] [PubMed]

60. Eltayb, A.; Wadenberg, M.-L.G.; Svensson, T.H. Enhanced cortical dopamine output and antipsychotic-like effect of raclopride with adjunctive low-dose L-dopa. Biol. Psychiatry 2005, 58, 337-343. [CrossRef] [PubMed]

61. Langlois, M.; Quintard, D.; Abalain, C. Synthesis of symmetrical Pseudopeptides as potential inhibitors of the human immunodeficiency virus-1 protease. Eur. J. Med. Chem. 1994, 29, 639-647. [CrossRef]

62. Christiaans, J.; Timmerman, H. Cardiovascular hybrid drugs: Combination of more than one pharmacological property in one single molecule. Eur. J. Pharm. Sci. 1996, 4, 1-22. [CrossRef]

63. Mahfouz, N.M.; Aboul-Fadl, T.; Diab, A.K. Metronidazole twin ester prodrugs: Synthesis, physicochemical properties, hydrolysis kinetics and Antigiardial activity. Eur. J. Med. Chem. 1998, 33, 675-683. [CrossRef]

64. Giannola, L.; Giammona, G.; Alotta, R. Pro-drugs of isoniazid: Synthesis and diffusion characteristics of acyl derivatives. Die Pharm. 1992, 47, 423-425.

65. Ducho, C.; Görbig, U.; Jessel, S.; Gisch, N.; Balzarini, J.; Meier, C. Bis-cyclosal-d4t-monophosphates: Drugs that deliver two molecules of bioactive nucleotides. J. Med. Chem. 2007, 50, 1335-1346. [CrossRef] [PubMed]

66. Felix, A.M.; Winter, D.P.; Wang, S.-S.; Kulesha, I.D.; Pool, W.R.; Hane, D.L.; Sheppard, H. Synthesis and antireserpine activity of peptides of L-dopa. J. Med. Chem. 1974, 17, 422-426. [CrossRef] [PubMed]

67. Di Stefano, A.; Mosciatti, B.; Cingolani, G.M.; Giorgioni, G.; Ricciutelli, M.; Cacciatore, I.; Sozio, P.; Claudi, F. Dimeric L-dopa derivatives as potential prodrugs. Bioorgan. Med. Chem. Lett. 2001, 11, 1085-1088. [CrossRef]

68. Cannazza, G.; Di Stefano, A.; Mosciatti, B.; Braghiroli, D.; Baraldi, M.; Pinnen, F.; Sozio, P.; Benatti, C.; Parenti, C. Detection of levodopa, dopamine and its metabolites in rat striatum dialysates following peripheral administration of L-dopa prodrugs by mean of HPLC-EC. J. Pharm. Biomed. Anal. 2005, 36, 1079-1084. [CrossRef] [PubMed]

69. Di Stefano, A.; Carafa, M.; Sozio, P.; Pinnen, F.; Braghiroli, D.; Orlando, G.; Cannazza, G.; Ricciutelli, M.; Marianecci, C.; Santucci, E. Evaluation of rat striatal L-dopa and da concentration after intraperitoneal administration of L-dopa prodrugs in liposomal formulations. J. Controll. Release 2004, 99, 293-300. [CrossRef] [PubMed]

70. Di Stefano, A.; Sozio, P.; Iannitelli, A.; Marianecci, C.; Santucci, E.; Carafa, M. Maleic-and fumaric-diamides of $(\mathrm{O}, \mathrm{O}$-diacetyl)-L-dopa-methylester as anti-Parkinson prodrugs in liposomal formulation. J. Drug Target. 2006, 14, 652-661. [CrossRef] [PubMed]

71. Anderson, B.D. Prodrugs for improved CNS delivery. Adv. Drug Deliv. Rev. 1996, 19, 171-202. [CrossRef]

72. Ohtsuki, S.; Terasaki, T. Contribution of carrier-mediated transport systems to the blood-brain barrier as a supporting and protecting interface for the brain; importance for CNS drug discovery and development. Pharm. Res. 2007, 24, 1745-1758. [CrossRef] [PubMed] 
73. Tamai, I.; Tsuji, A. Transporter-mediated permeation of drugs across the blood-brain barrier. J. Pharm. Sci. 2000, 89, 1371-1388. [CrossRef]

74. Rautio, J.; Gynther, M.; Laine, K. Lat1-mediated prodrug uptake: A way to breach the blood-brain barrier? Ther. Deliv. 2013, 4, 281-284. [CrossRef] [PubMed]

75. Peura, L.; Malmioja, K.; Huttunen, K.; Leppänen, J.; Hämäläinen, M.; Forsberg, M.M.; Rautio, J.; Laine, K. Design, synthesis and brain uptake of Lat1-targeted amino acid prodrugs of dopamine. Pharm. Res. 2013, 30, 2523-2537. [CrossRef] [PubMed]

76. Fernández, C.; Nieto, O.; Rivas, E.; Montenegro, G.; Fontenla, J.A.; Fernández-Mayoralas, A. Synthesis and biological studies of glycosyl dopamine derivatives as potential antiparkinsonian agents. Carbohydr. Res. 2000, 327, 353-365. [CrossRef]

77. Fernández, C.; Nieto, O.; Fontenla, J.A.; Rivas, E.; de Ceballos, M.L.; Fernández-Mayoralas, A. Synthesis of glycosyl derivatives as dopamine prodrugs: Interaction with glucose carrier glut-1. Organ. Biomol. Chem. 2003, 1, 767-771. [CrossRef]

78. Bonina, F.; Puglia, C.; Rimoli, M.G.; Melisi, D.; Boatto, G.; Nieddu, M.; Calignano, A.; Rana, G.L.; Caprariis, P.D. Glycosyl derivatives of dopamine and L-dopa as anti-Parkinson prodrugs: Synthesis, pharmacological activity and in vitro stability studies. J. Drug Target. 2003, 11, 25-36. [CrossRef] [PubMed]

79. Ruocco, L.; Viggiano, D.; Viggiano, A.; Abignente, E.; Rimoli, M.G.; Melisi, D.; Curcio, A.; Nieddu, M.; Boatto, G.; Carboni, E.; et al. Galactosylated dopamine enters into the brain, blocks the mesocorticolimbic system and modulates activity and scanning time in Naples high excitability rats. Neuroscience 2008, 152, 234-244. [CrossRef] [PubMed]

80. Giannola, L.I.; De Caro, V.; Giandalia, G.; Siragusa, M.G.; Lamartina, L. Synthesis and in vitro studies on a potential dopamine prodrug. Die Pharm. 2008, 63, 704-710.

81. De Caro, V.; Sutera, F.M.; Gentile, C.; Tutone, M.; Livrea, M.A.; Almerico, A.M.; Cannizzaro, C.; Giannola, L.I. Studies on a new potential dopaminergic agent: In vitro BBB permeability, in vivo behavioural effects and molecular docking evaluation. J. Drug Target. 2015, 23, 910-925. [CrossRef] [PubMed]

82. Mangas-Sanjuan, V.; González-Alvarez, M.; Gonzalez-Alvarez, I.; Bermejo, M. Drug penetration across the blood-brain barrier: An overview. Ther. Deliv. 2010, 1, 535-562. [CrossRef] [PubMed]

83. More, S.S.; Vince, R. Design, synthesis and biological evaluation of glutathione Peptidomimetics as components of anti-Parkinson prodrugs. J. Med. Chem. 2008, 51, 4581-4588. [CrossRef] [PubMed]

84. Ishikura, T.; Senou, T.; Ishihara, H.; Kato, T.; Ito, T. Drug delivery to the brain. Dopa prodrugs based on a ring-closure reaction to quaternary Thiazolium compounds. Int. J. Pharm. 1995, 116, 51-63. [CrossRef]

85. Cingolani, G.M.; Di Stefano, A.; Mosciatti, B.; Napolitani, F.; Giorgioni, G.; Ricciutelli, M.; Claudi, F. Synthesis of 1-(+)-3-(3-hydroxy-4-pivaloyloxybenzyl)-2, 5-diketomorpholine as potential prodrug of 1-dopa. Bioorgan. Med. Chem. Lett. 2000, 10, 1385-1388. [CrossRef]

86. Giorgioni, G.; Claudi, F.; Ruggieri, S.; Ricciutelli, M.; Palmieri, G.F.; Di Stefano, A.; Sozio, P.; Cerasa, L.S.; Chiavaroli, A.; Ferrante, C.; et al. Design, synthesis, and preliminary pharmacological evaluation of new imidazolinones as 1-dopa prodrugs. Bioorgan. Med. Chem. 2010, 18, 1834-1843. [CrossRef] [PubMed]

87. Rasmussen, G.J.; Bundgaard, H. Prodrugs of peptides. 15. 4-Imidazolidinone prodrug derivatives of enkephalins to prevent aminopeptidase-catalyzed metabolism in plasma and absorptive mucosae. Int. J. Pharm. 1991, 76, 113-122. [CrossRef]

88. Karaman, R. Prodrugs Design Based on Inter-and Intramolecular Processes; Nova Science Publishers, Inc.: New York, NY, USA, 2014; pp. 1-76.

89. Lipinski, C.A. Drug-like properties and the causes of poor solubility and poor permeability. J. Pharmacol. Toxicol. Methods 2000, 44, 235-249. [CrossRef]

90. Brime, B.; Ballesteros, M.; Frutos, P. Preparation and in vitro characterization of gelatin microspheres containing levodopa for nasal administration. J. Microencapsul. 2000, 17, 777-784. [PubMed]

Sample Availability: Samples of the compounds are not available from the authors. 